\title{
Inventarisasi Jenis Pangan Pokok Lokal di Pulau Sangihe, Sulawesi Utara
}

\section{Inventory of Local Food on Sangihe Island North Sulawesi}

\author{
Alin Liana1, Muh. Yunus ${ }^{1}$, dan Herman² \\ ${ }^{1}$ Program Studi Pendidikan Biologi, STKIP Pembangunan Indonesia \\ JI. Inspeksi Kanal CitraLand No. 10 Makassar, Indonesia \\ ${ }^{2}$ Yayasan Mitra Masyarakat \\ Perum Agape Griya Blok R No. 33 Minahasa Utara, Indonesia \\ Email: alyn.lyana@gmail.com
}

Diterima: 14 Juni 2021

Revisi: 22 November 2021

Disetujui: 22 November 2021

\begin{abstract}
ABSTRAK
Ketahanan pangan merupakan isu nasional yang melibatkan seluruh lapisan masyarakat. Permasalahan ketahanan pangan pada masyarakat kepulauan bukan hanya tentang ketersediaan pangan, tetapi juga tentang transportasi. Penelitian ini bertujuan untuk menginventarisasi ragam pangan pokok lokal masyarakat di Pulau Sangihe, Sulawesi Utara sebagai salah satu model diversifikasi pangan masyarakat kepulauan. Teknik pelaksanaan penelitian meliputi observasi, wawancara, dokumentasi, dan studi referensi. Data dianalisis secara deskriptif kualitatif. Penelitian ini menemukan 34 ragam pangan pokok lokal berdasarkan penamaan oleh masyarakat setempat. Pangan pokok tersebut meliputi beras, sagu, talas, uwi, ubi jalar, ubi kayu, enau, pisang lokal, dan jagung. Berdasarkan hasil observasi, ke-34 ragam pangan lokal tersebut dikategorikan dalam 13 spesies dari delapan familia tumbuhan.

kata kunci: inventarisasi, diversifikasi, pangan pokok lokal, Pulau Sangihe

\section{ABSTRACT}

Food security is a national issue that involves all levels of society. The problem of food security in archipelagic communities is not only about food availability but also transportation. This study aimed to take an inventory of local food variety of the people on Sangihe Island North Sulawesi as a model of food diversification for the archipelagic community. The research implementation techniques include observation, interviews, documentation, and reference studies. Data were analyzed descriptively qualitative. This study found 34 types of local foods based on their given names by local people. The local foods were rice, sago, taro, yam, sweet potato, cassava, palm sugar, local bananas, and corn. Based on observations, the 34 types of local food were categorized into 13 species from eight families.
\end{abstract}

keywords: inventory, diversification, local food, Sangihe Island

\section{PENDAHULUAN}

ndonesia mengalami ketergantungan pada beras sejak lama. Setiap tahun pemerintah menargetkan konsumsi beras berkurang sebanyak 2,1 persen per tahun. Konsumsi beras tahun 2019 sebesar 94,9 kg per kapita per tahun, pada tahun 2020 ditargetkan turun ke posisi $92,9 \mathrm{~kg}$ per kapita per tahun. Nilai konsumsi tersebut diharapkan terus menurun sampai $85 \mathrm{~kg}$ per kapita per tahun pada 2024 (Nasution \& Zuraya, 2020). Momentum pandemi COVID-19 menjadi pemicu untuk menyadarkan masyarakat akan keanekaragaman pangan lokal yang sudah dikenal masyarakat sejak lama.
Pulau Sangihe merupakan salah satu kepulauan terluar di sebelah utara Pulau Sulawesi. Masyarakat di Pulau Sangihe diketahui memiliki ragam pangan lokal yang melimpah. Dahulu pangan pokok masyarakat Sangihe adalah sagu, namun tergeser karena terjadi perubahan pola konsumsi pangan utama menjadi beras (Lintang, dkk., 2013). Selain sagu sebagai pangan pokok utama, masyarakat Sangihe juga menggunakan umbiumbian sebagai makanan pokok alternatif. Hasil penelitian Warsilah (2013) menunjukkan bahwa masyarakat desa pesisir Bahoi Minahasa yang biasa mengonsumsi pangan pokok campuran, ternyata berasal dari suku Sangir. Pangan 
pokok campuran yang dimaksud adalah pangan nonberas berupa singkong, ubi jalar, pisang, bete (talas/kimpul), dan jagung yang disajikan bersama-sama dengan pangan beras.

Penelitian ini bertujuan untuk menginventarisasi ragam pangan pokok lokal masyarakat di Pulau Sangihe sebagai suatu kekayaan biodiversitas kepulauan. Selain itu pemetaan keanekaragaman pangan pokok lokal diharapkan dapat membuka wawasan masyarakat tentang variasi pangan untuk tujuan diversifikasi pangan.

\section{METODOLOGI}

Penelitian ini dilaksanakan selama bulan Agustus-Oktober 2020 di Pulau Sangihe Kabupaten Kepulauan Sangihe. Metode penelitian dilakukan dengan survei, yang meliputi lima desa di tiga kecamatan, yaitu Desa Lapango di Kecamatan Manganitu Selatan, Desa Balane di Kecamatan Tamako, serta Desa Bowongkulu, Desa Lenganeng, dan Desa Utaurano di Kecamatan Tabukan Utara. Kelima desa tersebut dipilih sebagai lokasi sampling karena merupakan pusat pertanian

Tabel 1. Ragam Pangan Pokok Lokal Masyarakat di Pulau Sangihe

\begin{tabular}{|c|c|c|c|c|c|}
\hline No. & Nama Lokal & Nama IImiah & Familia & $\begin{array}{l}\text { Bagian yang } \\
\text { dimanfaatkan }\end{array}$ & $B / L^{*}$ \\
\hline 1. & Beras & Oryza sativa & Poaceae & Biji & B \\
\hline 2. & Humbia baruk & Arenga microcarpha & Arecaceae & Batang & $\mathrm{L}$ \\
\hline 3. & Humbia duri & Metroxylon rumphii & Palmae & Batang & $\mathrm{L}$ \\
\hline 4. & Humbia leno & Metroxylon sp. & Palmae & Batang & $\mathrm{L}$ \\
\hline 5. & Korlebu ungu/Bete cabu' & Colocasia sp. & Araceae & Umbi & $\mathrm{B}$ \\
\hline 6. & Korlebu putih/Bete cabu' & Colocasia sp. & Araceae & Umbi & B \\
\hline 7. & Korlewangka ungu/Bete gale & Colocasia sp. & Araceae & Umbi & B \\
\hline 8. & Korlewangka putih/Bete gale & Colocasia sp. & Araceae & Umbi & B \\
\hline 9. & Daluga & Cyrtosperma merkusii & Araceae & Umbi & $\mathrm{L}$ \\
\hline 10. & Daluga mentega & Cyrtosperma merkusii & Araceae & Umbi & $\mathrm{L}$ \\
\hline 11. & Daluga merah & Cyrtosperma merkusii & Araceae & Umbi & $\mathrm{L}$ \\
\hline 12. & Bigha & Alocasia macrorrhizos & Araceae & Umbi & $L$ \\
\hline 13. & Tapehe/Salawu & Dioscorea alata & Dioscoreaceae & Umbi & B \\
\hline 14. & Ima tinta & Ipomoea batatas & Colvolvulaceae & Umbi & B \\
\hline 15. & Ima hesau tamako & Ipomoea batatas & Colvolvulaceae & Umbi & B \\
\hline 16. & Apise mahamu & Ipomoea batatas & Colvolvulaceae & Umbi & B \\
\hline 17. & Batata kuning & Ipomoea batatas & Colvolvulaceae & Umbi & B \\
\hline 18. & Ima momase & Ipomoea batatas & Colvolvulaceae & Umbi & B \\
\hline 19. & Batata gunung & Ipomoea batatas & Colvolvulaceae & Umbi & $B$ \\
\hline 20. & Ima kapuk & Ipomoea batatas & Colvolvulaceae & Umbi & B \\
\hline 21. & Ima marinsade & Ipomoea batatas & Colvolvulaceae & Umbi & B \\
\hline 22. & Ima tere & Ipomoea batatas & Colvolvulaceae & Umbi & B \\
\hline 23. & Ima & Ipomoea batatas & Colvolvulaceae & Umbi & B \\
\hline 24. & Ima asmara & Ipomoea batatas & Colvolvulaceae & Umbi & B \\
\hline 25. & Kasebi bijole & Manihot utilissima & Euphorbiaceae & Umbi & B \\
\hline 26. & Kasebi ranting & Manihot utilissima & Euphorbiaceae & Umbi & B \\
\hline 27. & Kasebi apise & Manihot utilissima & Euphorbiaceae & Umbi & B \\
\hline 28. & Kasebi kacang & Manihot utilissima & Euphorbiaceae & Umbi & B \\
\hline 29. & Kasebi mentega deling & Manihot utilissima & Euphorbiaceae & Umbi & B \\
\hline 30. & Kasebi mentega luring & Manihot utilissima & Euphorbiaceae & Umbi & B \\
\hline 31. & Kasebi gabin & Manihot utilissima & Euphorbiaceae & Umbi & B \\
\hline 32. & Akele' & Arenga sp. & Arecaceae & Batang & $\mathrm{L}$ \\
\hline 33. & Hapang Kehu/pisang penjaga & Musa sp. & Musaceae & Buah & B \\
\hline 34. & Jagung & Zea Mays & Poaceae & Biji & B \\
\hline
\end{tabular}

Catatan: *B = Budidaya; $L$ = Liar (tumbuh secara alami) 

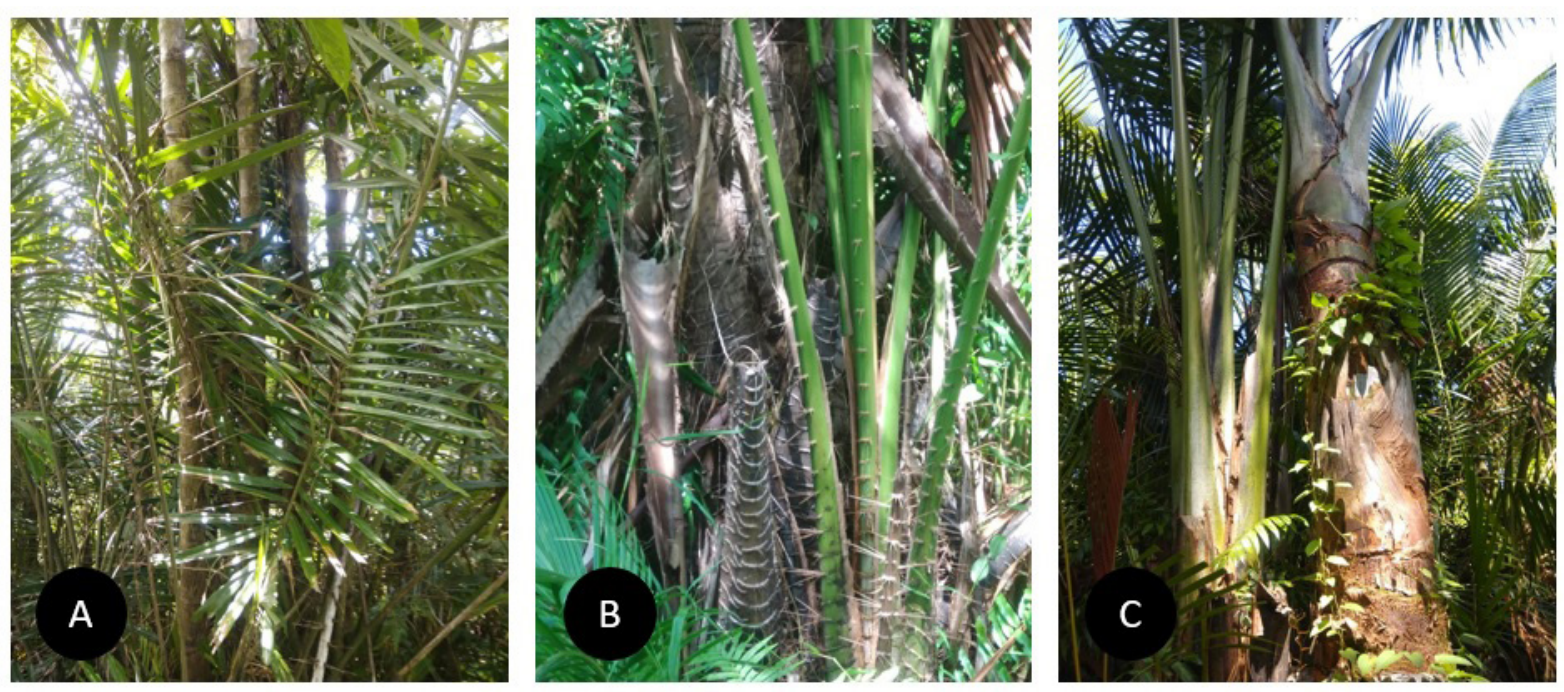

Gambar 1. Ragam Sagu di Pulau Sangihe; A. Sagu Baruk, B. Sagu Duri, C. Sagu Leno

dan perkebunan masyarakat setempat.

Teknik pelaksanaan penelitian meliputi observasi, wawancara, dokumentasi, dan studi referensi. Observasi dilakukan dengan mengunjungi Dinas Pertanian dan tokoh masyarakat setempat, untuk mengetahui data keanekaragaman pangan pokok masyarakat di Pulau Sangihe. Wawancara dilakukan secara semi terstruktur pada 12 orang warga yang terdiri atas pegawai Dinas Pertanian, kepala desa, petani, dan masyarakat. Dokumentasi dilakukan dengan membuat catatan hasil pengamatan dan foto objek penelitian. Studi referensi dilakukan dengan mengolah pustaka dan berita dari media yang berhubungan dengan objek yang dikaji. Data yang diperoleh dianalisis secara deskriptif kualitatif untuk diinterpretasikan dalam pembahasan.
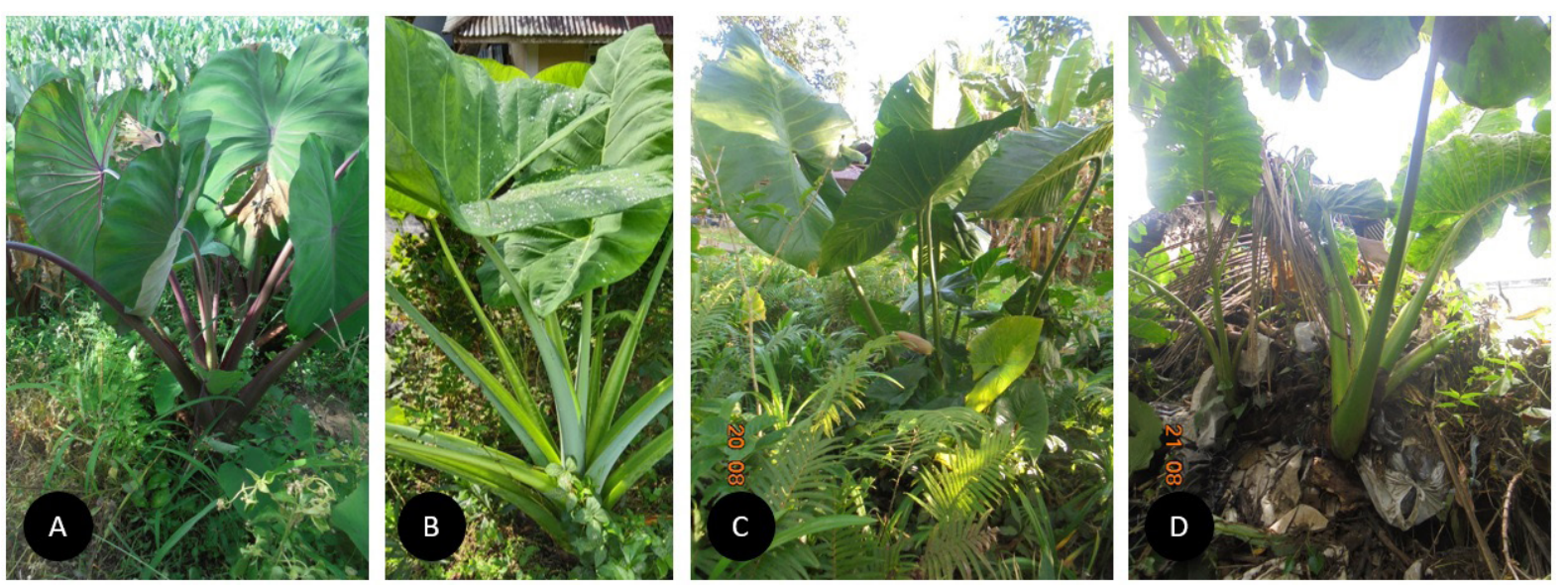

Gambar 2. Talas-talasan di Pulau Sangihe; A. Korlebu, B. Korlewangka, C. Daluga, D. Bigha

Pulau Sangihe merupakan salah satu pulau terluar di Kabupaten Kepulauan Sangihe yang berbatasan dengan Pulau Mindanao, Filipina. Letak geografis pulau tersebut dan sejarah masa lampaunya memungkinkan banyak ditemukan tumbuhan yang menjadi pangan pokok lokal bagi masyarakat setempat. Kekayaan ragam pangan pokok lokal membuat masyarakat seharusnya tidak tergantung pada satu jenis pangan pokok. Hal ini akan sangat menguntungkan masyarakat kepulauan yang seringkali sulit dijangkau. Selain itu, keragaman pangan pokok lokal akan meningkatkan ketahanan dan kemandirian pangan di wilayah tersebut.

Penelitian ini menemukan 34 ragam pangan pokok lokal berdasarkan penamaan oleh masyarakat setempat (Tabel 1). Pangan pokok 


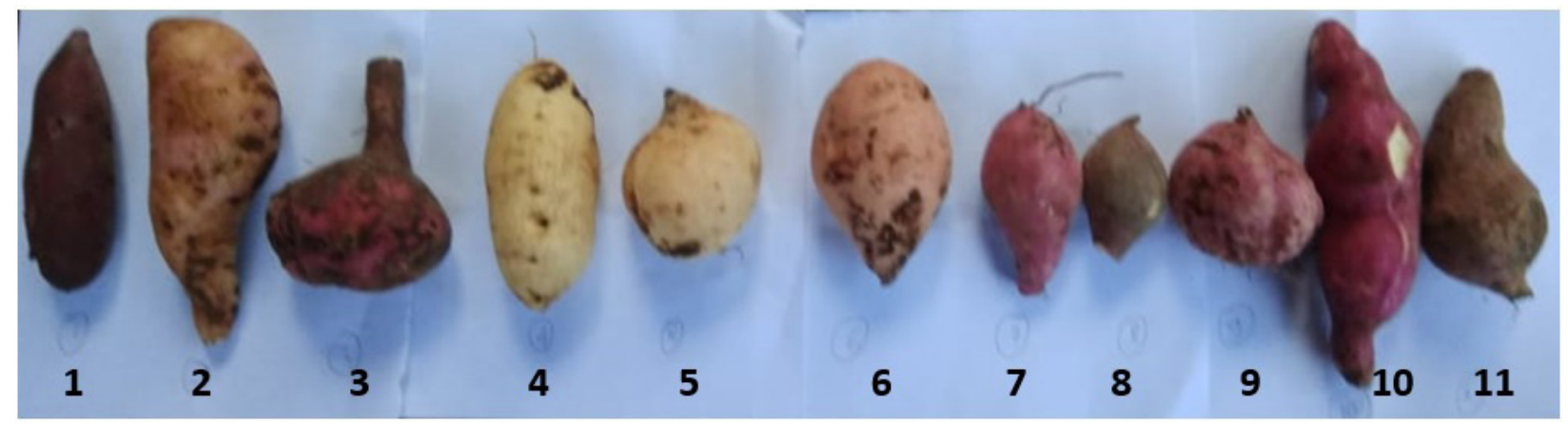

Gambar 3. Variasi Umbi Ubi Jalar di Pulau Sangihe; 1. Ima Tinta, 2. Ima Hesau Tamako, 3. Apise Mahamu, 4. Batata Kuning, 5. Ima Monase, 6. Batata Gunung, 7. Ima Kapuk, 8. Ima Marinsade, 9. Ima Tere, 10. Ima, 11. Ima Asmara

tersebut berasal dari beras, sagu, talas, uwi, ubi jalar, ubi kayu, enau, pisang lokal, dan jagung. Berdasarkan hasil observasi, ke-34 ragam pangan lokal tersebut dikategorikan dalam 13 spesies dari delapan familia tumbuhan dengan status 7 jenis sebagai tanaman budidaya dan 6 jenis sebagai tumbuhan liar. Beberapa pangan lokal dengan nama lokal yang berbeda diketahui berasal dari spesies yang sama. Pada beberapa spesies terdapat varietas yang belum dapat diidentifikasi dengan baik, yaitu Colocasia sp. terdapat 4 varietas, Ipomoea batatas 11 varietas, dan Manihot utilissima sebanyak 7 varietas.

Pangan pokok masyarakat Pulau Sangihe terdiri atas pangan beras dan nonberas. Ketersediaan beras yang diproduksi masyarakat lokal belum mencukupi untuk memenuhi kebutuhan pangan masyarakat setempat, sehingga harus didatangkan dari daerah lain. Namun, secara turun-temurun, masyarakat Sangihe telah memanfaatkan pangan nonberas sebagai sumber karbohidratnya (Pakasi, dkk.,
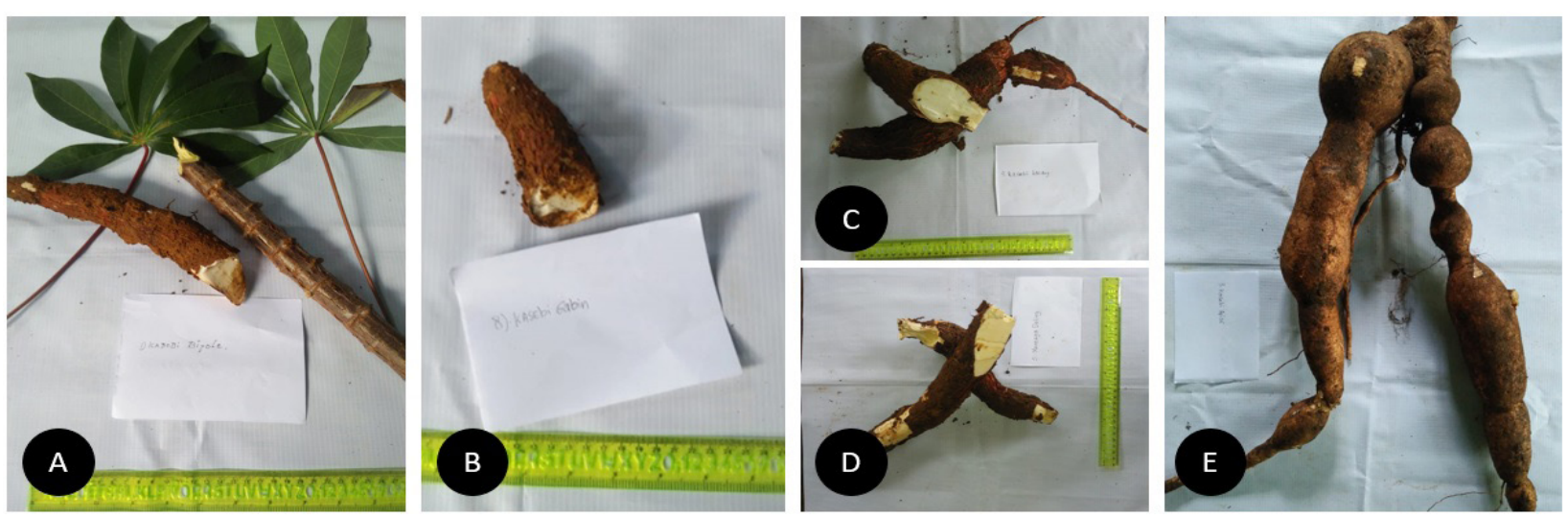

Gambar 4. Variasi Umbi Ubi Kayu di Pulau Sangihe; A. Kasebi Bijole, B. Kasebi Gabin, C. Kasebi Kacang, D. Kasebi Mentega Deling, E. Kasebi Apise 
juga mengembangkan produk inovasi olahan sagu menjadi mi, makaroni, kue biji-biji, dan aneka kue kering lainnya (Yapeka, 2018).

Jenis pangan alternatif setelah sagu adalah talas-talasan. Terdapat tiga jenis talas yang diketahui merupakan tanaman pangan bagi masyarakat Sangihe, yaitu bete/talas (Colocasia sp.), daluga (Cyrtosperma merkusii), dan bigha (Alocasia macrorrhizos). Pada masyarakat lokal, dikenal dua tipe bete, yaitu bete yang dipanen dengan cara dicabut disebut korlebu/ bete cabut (Gambar 2A) dan bete yang dipanen dengan cara digali disebut korlewangka/ bete gale (Gambar 2B). Masing-masing tipe memiliki umbi berwarna putih dan ungu. Talas telah dibudidayakan oleh masyarakat di semua kecamatan di Pulau Sangihe. Data BPS Kabupaten Kepulauan Sangihe menunjukkan bahwa produksi bete (talas) pada 2016 mencapai 769 ton. Jenis talas lain yang banyak digunakan sebagai bahan pangan alternatif adalah daluga, talas rawa raksasa dengan berat umbi mencapai $5 \mathrm{~kg}$ (Gambar 2C). Pada masyarakat lokal, daluga dikenal memiliki tiga varietas, yaitu daluga, daluga mentega, dan daluga merah. Pangan ini mempunyai arti penting bagi masyarakat Sangihe karena dapat menunjang ketahanan pangan mereka. Namun, menurut Lintang, dkk. (2016) jenis ini belum dibudidayakan secara luas, bahkan rawa tempat tumbuhnya telah banyak dikonversi menjadi sawah dan permukiman. Jenis talas lain yang juga dikonsumsi sebagai pangan alternatif oleh masyarakat setempat adalah bigha (Gambar 2D). Menurut masyarakat, bagian talas ini yang dimakan adalah batangnya. Namun, hasil penelitian Maretni (2017) mengidentifikasi bahwa bigha mengalami modifikasi batang berupa umbi, sehingga yang sesungguhnya dimakan adalah umbi yang menyerupai batang. Daluga dan bigha merupakan talas varietas lokal Pulau Sangihe yang belum dibudidayakan oleh masyarakat. Menurut masyarakat setempat, kedua jenis talas tersebut berukuran besar dan tumbuh di rawa-rawa sehingga sulit untuk dibudidayakan. Pengolahan umbi talas untuk bahan pangan pokok yaitu dengan direbus, selanjutnya dimakan bersama sayuran dan lauk-pauk. Bentuk olahan lain dapat berupa talas goreng, kolak talas, ataupun keripik talas.

Jenis pangan alternatif yang juga dibudidayakan masyarakat Pulau Sangihe adalah ubi jalar (Ipomoea batatas) dari familia Concolvulaceae. Masyarakat setempat menyebutnya ima atau batata. Ubi jalar ini memiliki varietas paling banyak jika dibandingkan dengan jenis pangan lokal lainnya, yaitu sebanyak 11 varietas. Setiap varietas dibedakan berdasarkan karakter morfologis tanaman, terutama umbinya. Setiap umbi memiliki warna, tekstur, bentuk, dan cita rasa yang khas (Gambar 3). Semua varietas tersebut dibudidayakan sebagai upaya diversifikasi dan menjaga ketahanan pangan masyarakat. Dari 15 kecamatan yang ada, hanya Kecamatan Tatoareng yang tidak memiliki lahan budidaya ubi jalar. Data BPS Kabupaten Kepulauan Sangihe menunjukkan bahwa pada tahun 2016 hasil produksi ubi jalar terbanyak terdapat di Kecamatan Tabukan Utara yaitu sebanyak 85,5 ton. Seperti halnya talas, masyarakat mengolah ubi jalar sebagai bahan pangan dengan cara direbus, selanjutnya dimakan bersama sayuran dan lauk pauk.

Tabel 2. Komposisi Energi dan Karbohidrat per 100 gram berbagai Pangan Pokok

\begin{tabular}{clccl}
\hline No. & $\begin{array}{c}\text { Bahan } \\
\text { Pangan }\end{array}$ & $\begin{array}{c}\text { Energi } \\
\text { (kkal) }\end{array}$ & $\begin{array}{c}\text { Karbohidrat } \\
(\mathbf{g})\end{array}$ & \multicolumn{1}{c}{ Pustaka Acuan } \\
\hline 1. & Beras Putih & 357 & 77,1 & Mahmud \& Zulfianto, 2009 \\
2. & Tepung Sagu & 353 & 84,7 & Direktorat Gizi, 1979 \\
3. & Umbi Talas & 98 & 23,7 & Direktorat Gizi, 1979 \\
4. & Uwi & 101 & $81,6-87,6$ & Udensi, dkk., 2012 \\
5. & Ubi Jalar & 123 & 27,9 & Balitbaki, 2001 \\
6. & Ubi Kayu & 154 & 36,8 & Mahmud \& Zulfianto, 2009 \\
7. & Jagung & 140 & 75 & Lalujan, dkk., 2017 \\
8. & Pisang & 116 & 31,15 & Wulandari, dkk., 2018 \\
\hline
\end{tabular}


Ubi kayu juga menjadi makanan pokok alternatif bagi masyarakat Pulau Sangihe. Diketahui terdapat tujuh varietas ubi kayu yang juga teridentifikasi berdasarkan morfologi umbinya (Gambar 4). Seperti halnya talas, ubi kayu juga dibudidayakan oleh masyarakat di seluruh kecamatan yang ada di Pulau Sangihe. Data BPS Kabupaten Kepulauan Sangihe menunjukkan bahwa ubi kayu menghasilkan panen terbesar yaitu 1.210 ton pada tahun 2016 tepatnya di Kecamatan Tabukan Selatan.

Selain empat komoditas nonberas utama, juga terdapat empat sumber pangan lokal alternatif yang tersedia, yaitu tapehe (uwi), akele (enau), hapang kehu (pisang penjaga), dan jagung. Tapehe dikenali dari morfologi tanaman yang tumbuh merambat, membedakan dari jenis umbi yang lain. Tapehe di Sangihe adalah varietas berwarna ungu. Akele dimanfaatkan batangnya untuk diambil patinya dan diolah seperti pengolahan sagu. Sementara itu pisang yang dijadikan sebagai pangan pokok merupakan pisang lokal Sangihe. Jagung juga dibudidayakan sebagai bahan pangan alternatif masyarakat Sangihe.

Dari keempat jenis tersebut, hanya Akele yang tidak dibudidayakan, karena masyarakat lebih memilih untuk mengolah sagu daripada enau. Saat ini masyarakat Sangihe sudah jarang memanfaatkan enau sebagai bahan pangan. Mereka telah mengetahui bahwa batang enau dapat diolah menjadi bahan pangan pokok, tetapi hanya akan digunakan dalam kondisi sangat membutuhkan. Komposisi energi dan karbohidrat per 100 gram berbagai pangan pokok disajikan pada Tabel 2 .

Secara umum, masyarakat Sangihe memanfaatkan pangan alternatif nonberas ini dengan cara direbus atau dikukus, kemudian disajikan di meja makan bersama sayuran dan lauk pauk. Hanya sagu dan enau yang melewati proses pengolahan lebih lama, yaitu dengan dibuat sebagai tepung sagu terlebih dahulu. Tepung sagu diolah secara tradisional sesuai kearifan lokal masyarakat Pulau Sangihe (Gambar 5).

Beras bukanlah komoditas utama bagi petani di Sangihe. Kebutuhan akan beras dapat terpenuhi seluruhnya jika dikirim dari daerah

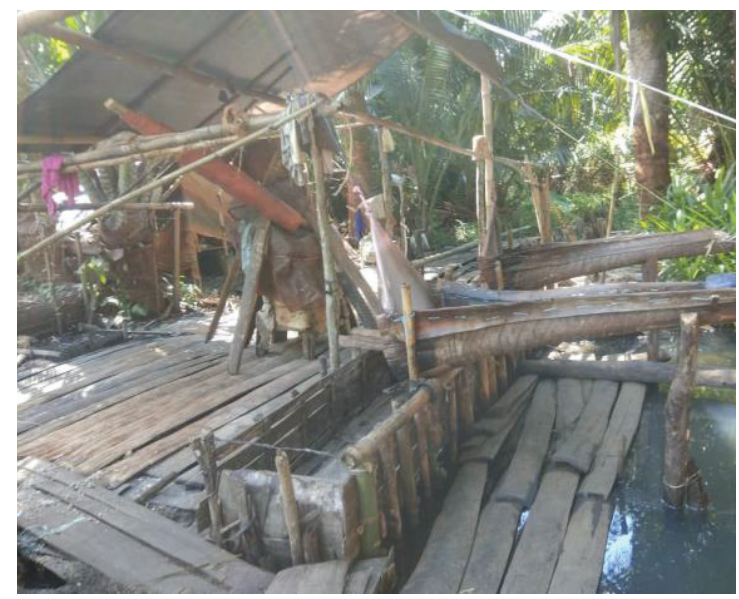

Gambar 5. Alat pengolah sagu, sebuah kearifan lokal

lain. Di sisi lain, keterbatasan pangan beras dipengaruhi oleh ketersediaan alat transportasi antar pulau yang tidak menentu, mengikuti kondisi cuaca dan kondisi geologis wilayah setempat. Pulau Sangihe diketahui sebagai salah satu daerah rawan bencana. Secara geologis, pulau tersebut berada pada rangkaian alur gunung api aktif dan merupakan tumbukan antara lempeng Sangihe dan Halmahera (Prawiradisastra, 2003). Kondisi tersebut membuat Pulau Sangihe rawan terhadap gempa bumi, letusan gunung api, banjir dan tanah longsor. Untuk mengantisipasi segala kemungkinan tersebut, diversifikasi pangan menjadi sesuatu yang penting untuk dilakukan.

Salah satu upaya diversifikasi pangan yang dilakukan oleh pemerintah setempat yaitu dengan program "Kembalikan Sangiheku" Dalam program ini, masyarakat diimbau untuk tidak makan nasi sebanyak dua hari dalam satu minggu. Pemerintah setempat menetapkan hari selasa dan jumat sebagai hari tanpa nasi setiap minggunya. Untuk membuktikan komitmen pemerintah dalam mengupayakan kembalinya sagu menjadi pangan pokok utama, pemerintah menyalurkan bantuan pangan pokok berupa sagu bagi warga mereka yang terdampak COVID-19 (Fakhruddin, 2020).

Upaya pemerintah melakukan diversifikasi pangan juga terlihat dengan keseriusan mereka dalam mendaftarkan varietas pangan lokal sebagai kekayaan biodiversitas mereka. Sejak tahun 2014 sagu baruk telah disahkan kepemilikannya atas nama pemerintah dan masyarakat Pulau Sangihe (Tenda, 2015). Pada 
tahun 2019 umbi daluga, bete, bigha, dan pisang penjaga juga didaftarkan sebagai varietas lokal Sangihe.

Pada tahun 2015, indeks ketahanan pangan di Kabupaten Kepulauan Sangihe adalah 0,42; berada dalam status cukup tahan (Pakasi, dkk., 2015). Pemetaan ragam pangan pokok lokal ini diharapkan dapat menyumbangkan peningkatan wawasan keanekaragaman hayati dan upaya diversifikasi pangan. Jika upaya diversifikasi pangan ini berhasil, bukan sekadar sebagai pangan substitusi, maka akan berdampak pada kemampuan masyarakat menyokong kebutuhan pangan mereka. Isu ketahanan pangan akan menjadi sesuatu yang dapat mereka taklukkan.

\section{KESIMPULAN}

Pulau Sangihe memiliki 13 spesies pangan pokok lokal yang merupakan gabungan tanaman budidaya dan tumbuhan liar. Pangan pokok lokal tersebut meliputi kelompok beras, sagu, talas, uwi, ubi jalar, ubi kayu, enau, pisang, dan jagung.

\section{UCAPAN TERIMA KASIH}

Penulis mengucapkan terima kasih kepada Ibu Miesjie Pontolawokang dan Dinda Dedy Arfansyah Tengahari, beserta seluruh narasumber yang telah membantu proses inventarisasi ragam pangan lokal di Pulau Sangihe.

\section{DAFTAR PUSTAKA}

Badan Pusat Statistik Kabupaten Kepulauan Sangihe. Tanggal diakses 20 Juni 2021.

Balitbaki. 2001. Deskripsi Varietas Unggul Ubi Jalar. Balai Tanaman kacang-kacangan dan Umbiumbian. Malang.

Direktorat Gizi Departemen Kesehatan RI. 1979. Daftar Komposisi Bahan Makanan. Bharata Karya Aksara. Jakarta.

Fakhruddin, M. 2020. Pemkab Sangihe Siapkan Sagu untuk Warga Terdampak COVID-19. Republika, 21 April 2020.

Lalujan, L.E., G.S.S. Djarkasi, T.J.N. Luju, D. Rawung, dan M.F. Sumual. 2017. Komposisi Kimia dan Gizi Jagung Lokal Varietas 'Manado Kuning' Sebagai Bahan Pangan Pengganti Beras. Jurnal Teknologi Pertanian. Vol 8 (1) Juni 2017: 47-54.

Lintang, M., P. Layuk, and Bahtiar. 2013. Potensi Pangan Lokal dalam Membangun Kemandirian Pangan di Kabupaten Kepulauan Sangihe. Di dalam E. Pasandaran, E. Ananto, K.
Suradisastra, N.S. Saad, B. Irawan, H. Soeparno, dan A. Hendriadi (eds.) Membangun Kemandirian Pangan Pulau-Pulau Kecil Wilayah Perbatasan. IAARD Press.

Lintang, M., P. Layuk, and G.H. Joseph. 2016. Karakteristik Tepung Umbi Daluga (Cyrtosperma mercusii), Wongkai (Dioscorea sp.), Kolerea (Colocasia sp.), dan Longki (Xanthosoma sp.) Asal Sulawesi Utara, Substitusi Terigu untuk Pangan Pokok. Jurnal Penelitian Pascapanen Pertanian. Vol 13 (2) September 2016: 84-91.

Mahmud, M.K. dan N.A. Zulfianto. 2009. Tabel Komposisi Pangan Indonesia (TKPI). PT Elex Media Komputindo. Jakarta.

Maretni, S., Mukarlina, M. Turnip. 2017. Jenis-jenis Tumbuhan Talas (Araceae) di Kecamatan Rasau Jaya Kabupaten Kubu Raya. Jurnal Protobiont. Vol 6 (1): 42-52.

Mendalora J. dan J.MR. Darondo. 2019. "Sagu Baruk" beri Peran Besar Penuhi Kebutuhan Pangan di Kepulauan Sangihe, Antara, 2 Agustus 2019.

Nasution, D.D. and N. Zuraya. 2020. Tahun Depan, Kementan Targetkan Penurunan Konsumsi Beras, Republika, 23 September 2020.

Pakasi, C.B.D., L. Sondakh, and M. Sondakh. 2015. Identifikasi Status Ketahanan Pangan dan Rantai Pasok Pangan di Daerah Perbatasan Provinsi Sulawesi Utara. Prosiding Seminar Nasional FKPTPI Fakultas Pertanian Universitas Lambung Mangkurat.

Prawiradisastra, S. 2003. Analisa Informasi Bencana Sebagai Dasar Pengembangan Wilayah di Kabupaten Kepulauan. Jurnal Alami. Vol. 8(3): 57-61.

Tulalessy, Q.D. 2016. Sagu sebagai Makanan Rakyat dan Sumber Informasi Budaya Masyarakat Inanwatan: Kajian Folklor Non Lisan. MELANESIA: Jurnal IImiah Kajian Sastra dan bahasa. Vol. 1(1): 85-91.

Yapeka, R. 2018. Melirik Budidaya Sagu Di Kepulauan Sangihe. Rumah Yapeka. https://yapeka.or.id/ budidaya-sagu-di-kepulauan-sangihe/ [diakses 23 juni 2021].

Yasyi, D.N. 2020. Mengungkap Asal Usul Sagu Porno dari Kepulauan Sangihe. Good News From Indonesia (GNFI), 16 juni 2020.

Tenda E.T. 2015. Varietas unggul Sagu Baruq Asal Kabupaten Sangihe. Balit Palma. https:// balitka.litbang.pertanian.go.id/varietas-unggulsagu-baruq-asal-kabupaten-sangihe/?lang=en [diakses 24 Juni 2021].

Udensi, E.A., H.O. Oselebe, O.O Iweala. 2012. The Investigation of Chemical Composition and Functional Properties of Water Yam (Dioscorea 
alata): Effect of Varietal Differences [2008]. Pakistan Journal of Nutrition. Vol 7 (2): 342-344.

Warsilah, H. 2013. Peran Foodhabits Masyarakat Pedesaan Pesisir dalam Mendukung Ketahanan Pangan: Kasus Desa Bahoi dan Bulutui di Kabupaten Minahasa Utara. Jurnal Masyarakat \& Budaya. Vol 15 (1): 97-130.

Wulandari, R.T., N. Widyastuti, dan M. Ardiaria. 2018. Perbedaan Pemberian Pisang Raja dan Pisang Ambon terhadap VO2max pada Remaja di Sekolah Sepak Bola. Journal of 14.

\section{BIODATA PENULIS:}

Alin Liana dilahirkan di Malang, 02 Juni 1983. Penulis menyelesaikan pendidikan S1 Program Studi Biologi Universitas Negeri Makassar pada tahun 2005; Pendidikan S2 Program Studi Biologi Universitas Gadjah Mada pada tahun 2010; dan Pendidikan S3 Program Studi IImu Biologi Universitas Gadjah Mada pada tahun 2017.

Muh. Yunus dilahirkan di Pallameang, 31 Desember 1964. Penulis menyelesaikan pendidikan S1 Program Studi Pendidikan Biologi IKIP Ujung Pandang pada tahun 1988; Pendidikan S2 Program Studi Pendidikan Kependudukan dan Lingkungan Hidup Universitas Negeri Makassar pada tahun 2005, dan Pendidikan S3 Program Studi Sosiologi Universitas Negeri Makassar pada tahun 2013.

Herman dilahirkan di Ujung Pandang, 19 September 1981. Penulis menyelesaikan pendidikan S1 Program Studi Gizi Masyarakat dan Sumberdaya Keluarga Institut Pertanian Bogor pada tahun 2005. 


\section{PETUNJUK PENULISAN "PANGAN"}

\section{ISI DAN KRITERIA UMUM}

Pangan, terbit 3 (tiga) kali setahun, adalah jurnal nasional terakreditasi dengan peringkat 2 oleh Kementerian Riset, Teknologi, dan Pendidikan Tinggi Rl nomor 28/E/KPT/2019. Jurnal Pangan mempublikasikan artikel ilmiah (research article), kajian (review) tentang pangan, baik sains maupun terapan dan tulisan lainnya yang berkaitan dengan pangan. Redaksi menerima tulisan dari semua bidang ilmu yang terkait dengan komoditi pangan dari segala sumber. Komoditi pangan yang dimaksud adalah beras, jagung, kedelai, gula, minyak goreng, tepung terigu, bawang merah/putih, cabe daging sapi, daging ayam ras, dan telur ayam. Ruang lingkup penulisan meliputi aspek-aspek yang berkaitan dengan produksi, pengolahan, penyimpanan, transportasi, pemasaran, perdagangan, konsumsi dan gizi, sarana, teknologi, jasa, pendanaan, dan kebijakan. Tulisan yang dikirim ke redaksi adalah tulisan yang belum pernah dipublikasikan atau tidak sedang diajukan pada majalah/jurnal lain.

Tulisan ditulis dalam bahasa Indonesia sesuai kaidah bahasa yang digunakan. Tulisan harus selalu dilengkapi dengan Abstrak dwibahasa (Indonesia dan bahasa Inggris). Tulisan yang diajukan harus disertai biodata penulis yang berisi nama lengkap penulis, tempat tanggal lahir, jabatan penulis, instansi penulis beserta alamatnya, riwayat pendidikan penulis, dan alamat email. Tulisan yang isi dan formatnya tidak sesuai dengan pedoman penulisan "Pangan" akan ditolak oleh Redaksi dan Redaksi tidak berkewajiban untuk mengembalikan tulisan tersebut.

\section{KATEGORI TULISAN}

Artikel Ilmiah (Research Article) (sekitar 8-20 halaman jurnal). Artikel yang diajukan berisi kemajuan utama (major advance) yang merupakan original research findings. Artikel ilmiah harus mencakup abstrak, pandahuluan, bagianbagian dengan sub-judul (sub-heading) ringkas, dan maksimum 40 referensi. Materi dan metode harus dimasukkan guna menunjang material online, yang juga harus memasukkan informasi lain yang dibutuhkan untuk mendukung kesimpulan.

Kajian (Review) (sekitar 8-20 halaman jurnal) mendeskripsikan perkembangan baru kesignifikanan interdisiplin dan menyorot pertanyaan-pertanyaan yang belum teresolusi serta arahnya di masa mendatang. Semua review akan melalui proses pengkajian oleh peer-reviewer. Review yang dikirim harus memuat abstrak, pandahuluan, bagian-bagian dengan sub-judul (sub-heading) ringkas, dan maksimum 40 referensi.

Tulisan selain artikel ilmiah dan kajian yang berkaitan dengan pangan (sekitar 2-8 halaman jurnal) menyajikan hal-hal seperti kebijakan-kebijakan baru dan penting dengan kesignifikanan yang luas, baik skala nasional maupun internasional, komentar terhadap masalah pangan, diseminasi undang-undang, Peraturan Pemerintah, Inpres, Keppres, bedah buku, wawancara.

Tulisan yang dikirim diprioritaskan yang berskala nasional dan internasional.

\section{SELEKSI NASKAH}

Pertama, Proses pengajuan dan review tulisan dilakukan baik lewat hardcopy maupun softcopy.

Kedua, Tulisan yang dipertimbangkan untuk di review adalah yang memenuhi persyaratan penulisan sesuai petunjuk penulisan.

Ketiga, Semua tulisan yang telah memenuhi tata cara penulisan akan diberikan penilaian tentang kepantasan pemuatannya oleh Dewan Editor (Board of Reviewing Editors).

Keempat, Tulisan yang layak diterbitkan akan diproses lebih lanjut. Waktu yang dibutuhkan untuk proses penelaahan oleh dewan editor dan mitra bestari paling lama 8 minggu setelah tulisan diterima.

Kelima, Tulisan yang tidak dapat diterbitkan akan diberitahukan kepada penulis via e-mail.

\section{FORMAT PENULISAN}

Umum. Seluruh bagian dari tulisan termasuk judul, abstrak, judul tabel dan gambar, catatan kaki dan daftar acuan diketik satu spasi pada electronic file dan print out dalam kertas ukuran A4. Pengetikan dilakukan dengan menggunakan huruf (font) Arial berukuran 11 point dengan jarak spasi 1 (spasi) dan jarak antar paragraph 6 point.

Setiap halaman diberi nomor serta secara berurutan termasuk halaman gambar dan tabel. Hasil penelitian atau ulas balik/ tinjauan ditulis minimal 8 lembar dan maksimal 20 lembar, termasuk gambar dan tabel. Selanjutnya susunan naskah dibuat sebagai berikut :

Tulisan ilmiah dari hasil penelitian harus mempunyai struktur sebagai berikut :

Judul (Titles) makalah ilmiah bahan publikasi hasil riset semestinya menonjolkan fenomena yang diteliti (objek 
riset). Judul bukan metode dan juga bukan kegiatan (proyek). Judul tidak tidak terlalu panjang dimana fungsi aneka kata kunci terkait jelas. Judul dibuat dalam dua bahasa yaitu bahasa Indonesia dan bahasa Inggris serta ditulis dengan jenis huruf Times New Roman ukuran 16 point. Pada bagian bawah judul dicantumkan identitas penulis yang memuat nama penulis, lembaga dan alamat lembaga serta alamat e-mail.

Abstrak (abstracts) menjelaskan kepada pembaca umum kenapa riset dilakukan dan kenapa hasilnya penting. Abstrak tidak lebih dari 200 kata, mengemukakan poin-poin utama tulisan dan outline hasil atau kesimpulan. Abstrak ditulis dalam satu paragraf dan mengandung poin-poin sebagai berikut : (i) Alasan riset dilakukan (the purpose and objective of the study; the central question); (ii) Pernyataan singkat apa yang telah dilakukan (what was done; the method); (iii) Pernyataan singkat apa yang telah ditemukan (what was found; the result); dan (iv) Pernyataan singkat tentang kesimpulan (what was concluded; discussion). Abstrak harus ditulis dalam dwibahasa (Indonesia dan Inggris). Abstrak juga harus disertai dengan kata kunci (keywords) antara 3-6 kata dan ditulis dalam dwibahasa.

Pendahuluan, berisi penjelasan padat dan ringkas tentang latar belakang penelitian, tujuan penulisan atau menggambarkan apa yang akan disampaikan dalam tulisan secara jelas namun tidak terlalu berlebihan. Pendahuluan harus didukung oleh sumber pustaka yang memadai khususnya pustaka primer dan jelas menunjukkan perkembangan dari materi penulisan.

Metodologi berisikan disain penelitian yang digunakan, populasi, sampel, sumber data, instrumen, analisis dan teknik analisis yang digunakan.

Hasil dan pembahasan Hasil adalah temuan penelitian yang disajikan apa adanya tanpa pendapat penulis dan pembahasan menjelaskan dengan baik serta argumentatif tentang temuan penelitian serta relevansinya dengan penelitian terdahulu.

Kesimpulan menjawab tujuan penelitian tanpa melampauinya. Bila ada rekomendasi penelitian, dapat dimasukkan dalam subbab kesimpulan.

Daftar Pustaka, bagian ini berisi sumber rujukan yang digunakan dalam penulisan ilmiah tersebut. Ditulis dengan menggunakan sistem Chicago dan disusun menurut abjad. Daftar pustaka ditulis dengan menggunakan jenis huruf arial ukuran 10 point.

Biodata Penulis berisi nama lengkap penulis, tempat tanggal lahir, jabatan dan instansi penulis, riwayat pendidikan serta alamat email. Biodata penulis ditulis dengan menggunakan jenis huruf arial ukuran 10 point.

Tulisan ilmiah dari hasil penelitian, apabila penulis perlu menyampaikan ucapan terimakasih dapat dimasukkan dalam tulisan dan diletakkan sebelum daftar pustaka.

Tulisan ilmiah yang berbentuk kajian (bukan hasil penelitian murni) memiliki struktur seperti diatas namun tidak harus mencantumkan metode penelitian dalam subbab tersendiri.

Tulisan lain yang berkaitan dengan pangan, struktur penulisannya disesuaikan dengan isi.

\section{Contoh Penulisan Daftar Pustaka :}

\section{Buku}

Sawit, M. Husein dan Erna Maria Lakollo. 2007. Rice Import Surge in Indonesia. Bogor : ICASEPS and AAI.

\section{Terjemahan}

Kotler, Philip. 1997. Manajemen pemasaran : Analisis, perencanaan, implementasi (Hendra Teguh \& Ronny Antonius Rusli, Penerjemah.). Jakarta: Prenhallindo.

\section{Seminar}

Notohadiprawiro, T. dan J.E. Louhenapessy. 1992. Potensi Sagu Dalam Penganekaragaman Bahan Pangan Pokok Ditinjau Dari Persyaratan Lahan. Makalah disampaikan pada Simposium Sagu Nasional. 12-13 Oktober. Ambon.

\section{Bab dalam Buku}

Suismono dan Suyanti. 2008. Sukun sebagai Sumber Pangan Pokok Harapan dalam Penganekaragaman Konsumsi Pangan. Di dalam Wisnu Broto dan S. Prabawati (eds) Teknologi Pengolahan untuk Penganekaragaman Konsumsi Pangan. BB Pascapanen.

\section{Artikel Jurnal}

Morthy S.N. 1983. Effect of Some Physical and Chemical Treatment on Cassava Flour Quality. Journal of Food Science and Technology. Vol. 20. Nov/Dec : 302-305. 


\section{Surat Kabar}

Santoso, D. A.. 2009. Kedaulatan vs Ketahanan Pangan. Kompas, 13 Januari 2009.

\section{Prosiding}

Manurung, S.O. dan S. Partohardjono. 1984. Prospek Penggunaan Sitozim Sebagai Komponen Teknologi Untuk Meningkatkan Hasil Padi. Prosiding Simposium Padi. Bogor : Puslitbangtan.

\section{Publikasi Dokumen Pemerintah}

Biro Pusat Statistik. 1990. Struktur Ongkos Usaha Tani Padi dan palawija. Jakarta : BPS.

\section{Skripsi/tesis/disertasi}

Brotodjojo, R.R.R. 2007. Host searching behaviour of a generalist egg parasitoid - responses to alternative hosts with different physical characteristics. PhD Thesis at The University of Queensland, 180h.

\section{Situs Web}

Khomsan A. 2006. Beras dan Diversifikasi Pangan. http://kompas.com/kompas-cetak/0612/21/opini/3190395.htm [diakses 09 Feb 2008]

Tabel harus disusun secara jelas dan sesingkat mungkin. Penyusunan tabel harus memperhatikan hal-hal sebagai berikut : (i) tabel harus dapat dibaca dan dipahami secara tersendiri tanpa mengacu atau mengaitkannya dengan uraian pada teks, (ii) judul tabel harus dapat menggambarkan pemahaman terhadap isi tabel, (iii) pencantuman tabel sedekat mungkin dengan uraiannya pada teks, bila letak tabel berbeda halaman misalnya dua atau tiga halaman setelah uraian pada teks maka uraian dalam teks harus mencantumkan nomor tabel, dan bila agak jauh (melebihi tiga halaman) maka cantumkanlah nomor tabel dan halaman tabel. Penyusunan tabel harus memenuhi beberapa persyaratan yaitu : (i) Tabel dicantumkan pada kertasa teks dan simetris terhadap ruang ketikan kiri dan kanan, (ii) Tabel diberi nomor urut dengan angka arab dan diikuti dengan judul tabel yang diletakkan simetris di atas tabel. Bila judul tabel lebih dari satu baris, maka baris kedua dan selanjutnya dimulai sejajar dengan huruf pertama judul tabel pada baris pertama, (iii) Tabel yang terdiri kurang dari satu halaman dapat diletakkan langsung dibawah teks pada naskah yang bersangkutan, dan bila lebih dari satu halaman teks dapat dilakukan dengan dilanjutkan pada halaman berikutnya dengan mencantumkan nomor tabel dan kata lanjutan tanpa disebutkan judul tabelnya atau diletakkan pada lampiran, (iv) tabel yang memuat kutipan dari data sekunder harus mencantumkan sumber kutipan pada bagian bawah kiri sesudah tabel, (v) tabel dibuat satu dimensi tanpa garis batas yang memisahkan antar kolom.

Gambar yang disajikan harus berkaitan dengan uraian pada naskah. Gambar dapat dibentuk bagan/diagram, grafik, peta maupun foto. Penyusunan gambar harus memperhatikan beberapa hal seperti halnya tabel, namun judul gambar diletakkan dibagian bawah gambar tersebut.

\section{PENGIRIMAN}

Penulis dapat mengirimkan tulisan dalam bentuk softcopy melalui email ke : redaksi@jurnalpangan.com

Penulis juga dapat mengirimkan tulisan dalam bentuk compact disk(CD) yang harus disiapkan dengan Program Microsoft Word dan dikirim ke :

\section{Redaksi Jurnal Pangan}

Perum BULOG, Pusat Renstra, dan Manrisk, Lt 11 Gedung BULOG 1

J1. Gatot Subroto Kav 49, Jakarta Selatan, 12950.

Telp . (021) 5252209 ext. 2123, 2131, 2103

Pengiriman naskah harus disertai dengan surat resmi dari penulis penanggung jawab/korespondensi (corresponding outhor), yang harus berisikan dengan nama jelas penulis korespondensi, alamat lengkap untuk surat menyurat, nomor telephone dan faks, serta alamat email dan telephon genggam jika memiliki. Penulis korespondensi bertanggungjawab atas isi naskah dan legalitas pengiriman naskah yang bersangkutan. Naskah juga sudah harus diketahui dan disetujui oleh seluruh anggota penulis dengan pernyataan tertulis. 
Halaman ini sengaja dikosongkan 